\title{
A tanítás mint értelmiségi hivatás
}

\author{
Jilly Viktor
}

Budapesti Fazekas Mihály Gyakorló Általános Iskola és Gimnázium, angoltanár viktor.jilly@gmail.com

Révész fudit (2018): A tanítás mint értelmiségi hivatás. Tanulmány a pedagógusok kollektív mobilitási esélyeiről. Közép- és Kelet-európai Történelem és Társadalom Kutatásáért Közalapítvány, Budapest. 260 oldal

DOI: 10.37205/TEL-hun.2019.1-2.09

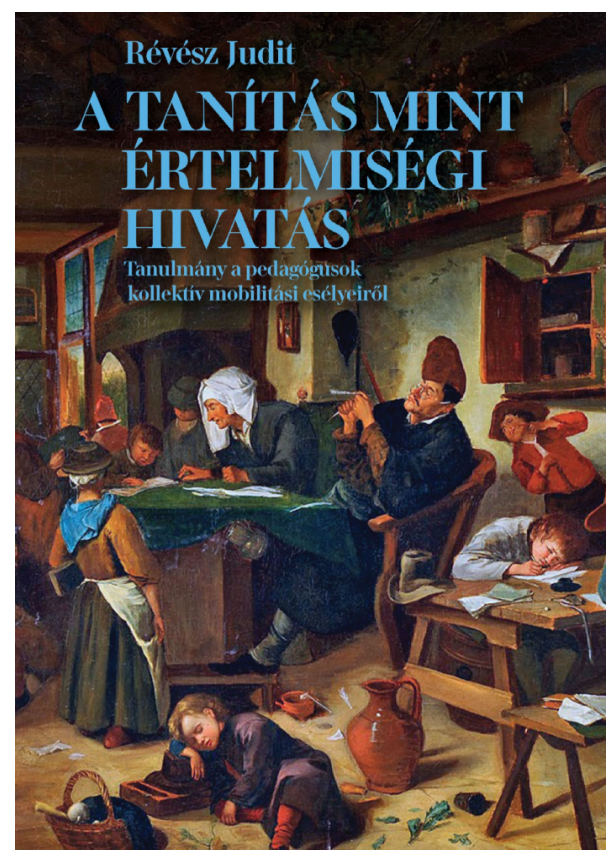

Amikor elolvastam Révész fudit tanulmányát, A tanitás mint értelmiségi hivatást, eszembe jutott, milyen büszke is voltam gyerekkoromban édesanyámra. Hányszor, de hányszor élveztem ki azt a pillanatot, amikor megkérdezték tőlem, mi anyukád foglalkozása, és én dagadó kebellel válaszoltam: baleseti sebész. A hatás sohasem maradt el: elismerően tágra nyíló szem, a megdöbbenéstől magasba szökő szemöldök és leesett áll. Még jó, hogy ezt gyerekkoromban átélhettem, mert amikor felnőttkoromban a saját foglalkozásomat említettem, miszerint tanár vagyok, a fent bemutatott, és nekem olyan jóleső reakció mindig elmaradt. Sokszor töprengtem el azon, hogy az a foglalkozás, amelyet a középkorban nem övezett különösebb dicsfény - hiszen a felcser borotvált is, meg mütéteket is végzett -, hogyan nőhetett társadalmi elismertség szintjén egy olyan, véleményem szerint sokkal összetettebb és jóval több kreativitást igénylő mesterség fölé, mint a tanítás. Révész Fudit tanulmánya többek között erre a kérdésemre is kimerítő választ adott.

A könyv egy olyan nyelvtanár műve, aki nem felejtette el tanárjelölti élményeit a gyakorlóiskolában, aki élénken emlékszik a nyelviskolában tanárként eltöltött évekre, és aki rengeteg tapasztalatot halmozott fel tanárképzőként az ELTE Angol Nyelvpedagógiai Tanszéken. Révész Judit tanulmánya a következő alapkérdésekre 
keresi a választ. Tisztában vagyunk-e azzal, hogy a diák tulajdonképpen mit is tanul, vagy jobban mondva, mit is sajátít el az iskolában, és a pedagógusnak mi a felelőssége ebben a folyamatban? A tanári hivatás az orvosi, a jogi vagy a papi hivatással összevetve milyen egyezéseket és főleg milyen különbségeket mutat? A jelenlegi struktúra megfelelően szüri-e a tanári pályára kerülő pedagógusokat? Az iskolákban a tanárjelölteket fogadó mentoroknak jelenleg milyen a kapcsolata a képzőintézményekkel, illetve ennek a kapcsolatnak milyennek kellene lennie? A könyv célját pedig az alcím nevezi meg a legpontosabban: Tanulmány a pedagógusok kollektív mobilitási esélyeiről. Azaz, ha a tanári szakma, professzió vagy hivatás - a megfelelő szó kiválasztásában a könyv majd segíteni fog - szeretné elérni azt a magas társadalmi elismertséget és védettséget, amelyet az orvosi, a jogi vagy a papi professzió már elért, akkor mi a teendő. A könyvet áthatja a szerző jogos elégedetlensége, amelyet a tanári professzió állapotával kapcsolatban érez -, és ennek a helyzetnek az okát az elmúlt 150 év távlatából érteti meg az olvasóval is. Emellett áthatja a tanári professzió iránt érzett szeretet és felelősség, és az a hit, hogy a helyzet jobbá tehető. A hatékony előrehaladás érdekében Révész Judit számos javaslatot is megfogalmaz.

A könyv az elméleti fejtegetések és az empirikus vizsgálatok szerencsés ötvözete. Ez megmutatkozik a szerkezeti felépítésben. A tanulmány első két fejezete Wenger szociális tanuláselmélete, illetve a hagyományos értelmiségi hivatások és a tanári professzió közötti különbségek összevetése - inkább izgalmas elméleti fejtegetés. A könyv utolsó két nagy egysége - mikor és hogyan rostálja vagy nem rostálja ki magából a rendszer az alkalmatlan pedagógusokat, illetve a mentortanárok és a képzőintézmények kapcsolata -, pedig inkább empirikus vizsgálat. Azért használtam az „inkább” szót, mert a fejezeteken belül is érvényesül az elmélet és a gyakorlat összefonódása. Révész fudit, jó tanárhoz illően, egy elvontabb gondolatot azonnal gyakorlati példákkal tesz szemléletessé, ettől válnak a legelvontabb szociológiai vagy neveléselméleti fejtegetések is könnyen emészthetővé. A gyakorlati példákat sokszor saját életéből veszi, ami nemcsak szemléletessé, de személyessé is teszi a magyarázatot. Szintén elősegíti ennek a tudományos műnek könnyű befogadását, hogy a szerző a magyarázatokat és a példákat többször is kiváló humorral füszerezi.

Az előző bekezdésekben nagyon is leegyszerüsítettem - reményeim szerint meglehetősen pontosan - a tanulmány legfontosabb felvetéseit és az azokra adott válaszait. De nem az a célom ezzel a könyvismertetéssel, hogy részletesen bemu- 
tassam Wenger szociális tanuláselméletét, vagy hogy összegezzem, hogyan írja le Freidson a professzionizmus ideáltípusát. Ezeket könyvében mind megteszi Révész fudit. Sokkal inkább az a célom, hogy kedvet ébresszek e könyv elolvasására.

Jómagam több évtizede nyelvtanárként tevékenykedem a közoktatásban, és elég sokat gondolkodtam a diák iskolában elfoglalt helyzetéről, a tanári pálya presztízséről, a pedagógus felelősségéről és az előrelépés lehetőségeiről. Nem hittem volna, hogy találok egy olyan könyvet, amelynek olvasása közben folyton azt érzem, hogy ezekre az engem régóta foglalkoztató kérdésekre történelmi távlatokba helyezett és meggyőző válaszokat kapok. Talán mindenki számára ismerős az a helyzet, amelyet egy jó könyv olvasása közben szoktunk érezni : én is valami ilyesmire gondoltam, csak nem tudtam ilyen jól megfogalmazni. Révész fudit könyvének olvasása közben többször átéltem ezt az élményt.

Ajánlom A tanitás mint értelmiségi hivatás címü igényesen szerkesztett és szép kivitelủ könyvet minden olyan olvasónak, aki szívén viseli a magyar oktatás ügyét, aki szeretné megérteni, hogy milyen égető problémákkal küzdünk ma, és hogy ezek a problémák miből erednek, valamint hogy milyen lépéseket kellene tennünk a helyzet javítása érdekében. Elsősorban persze a közoktatásban és a felsőoktatásban tevékenykedő kollégák figyelmét szeretném felhívni Révész fudit tanulmányára, de rendkívül hasznos lenne, ha a döntéshozók kezébe is eljutna ez a kötet. 